\title{
INTERNAL JUGULAR VEIN CATHETERISATION: A COMPARISON BETWEEN ULTRASOUND-GUIDED TECHNIQUE WITH LANDMARK-GUIDED TECHNIQUE
}

\author{
Vijayanand Siddalingappa ${ }^{1}$, Chaya Seshaiah², Chandrashekhar Krishna Reddy³
}

${ }^{1}$ Associate Professor, Department of Anaesthesiology, Kempegowda Institute of Medical Sciences, Bengaluru.

${ }^{2}$ Professor, Department of Anaesthesiology, Kempegowda Institute of Medical Sciences, Bengaluru.

3Professor, Department of Anaesthesiology, Kempegowda Institute of Medical Sciences, Bengaluru.

\section{ABSTRACT}

\section{BACKGROUND}

Central venous cannulation is an essential lifeline for the fluid and pressure management for various indications. It is also a cornerstone in invasive monitoring. Central venous cannulation with the assistance of ultrasound and Doppler has gained popularity in recent times over conventional landmark-guided technique.

\section{AIM}

To evaluate ultrasound-guided technique against traditional landmark technique for cannulation of right internal jugular vein with regard to safety, rapidity and feasibility.

\section{METHODOLOGY}

A study was conducted on 60 patients aged above 18 years requiring central venous cannulation for various indications with landmark (Group I) and USG (Group II) guided techniques. The right IJV was cannulated by Seldinger technique using landmarks of neck in SCM triangle and portable ultrasound of $5 \mathrm{MHz}$ for real-time images. The standard J-tip guidewire and 16-G catheter was used. The variables among the two groups such as the preparation time, access time, number of attempts to cannulate and complications like skin haematoma, carotid artery puncture, misplacement and pneumothorax were compared.

\section{RESULTS}

The preparation and access times for group I were higher (189.83 sec \pm 12.54 and $268.823 \mathrm{sec} \pm 274.93$ respectively) compared to that of group II (124.00 sec \pm 36.37 and $114.37 \mathrm{sec} \pm 87.44$ respectively). In group I only 10 (33.32\%) cases were cannulated in first attempt, while it was $21(70.00 \%)$ in group II. The complication rate were $13.33 \%$ in group II against $23.33 \%$ in group I.

\section{CONCLUSION}

The ultrasound-guided technique is superior to the traditional landmark-guided technique for the cannulation of right IJV with respect to speed, number of attempts and lesser number of complications.

\section{KEYWORDS}

Central Venous Cannulation, Internal Jugular Vein, Sternocleidomastoid, Carotid Artery, Ultrasound.

HOW TO CITE THIS ARTICLE: Siddalingappa V, Seshaiah C, Reddy CK. Internal jugular vein catheterisation: a comparison between ultrasound-guided technique with landmark-guided technique. J. Evolution Med. Dent. Sci. 2016;5(72):5296-5301, DOI: $10.14260 /$ jemds/2016/1200

\section{INTRODUCTION}

With advanced knowledge in medical monitoring, ever increasing value has been placed on the establishment of a central venous catheter. During the past forty years, there has been an enormous increase in the use of central venous catheterisation for various indications. ${ }^{1}$

Central venous cannulation became popular during 1970s when widespread application of total parenteral nutrition popularised subclavian vein cannula placement, the Seldinger technique and J-tip guidewire made central venous cannulation through the external jugular vein practical and the balloon-tipped pulmonary artery catheter was introduced and accepted.

Financial or Other, Competing Interest: None.

Submission 12-05-2016, Peer Review 24-08-2016,

Acceptance 31-08-2016, Published 08-09-2016.

Corresponding Author:

Dr. Vijayanand Siddalingappa,

\#27/36, 10 C Main Road, Next to PTA School,

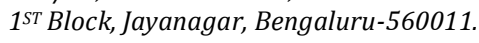

E-mail:dr.vanand@rediffmail.com

DOI: $10.14260 /$ jemds/2016/1200
The introduction of these techniques has allowed the optimal adjustment of circulatory variables by direct haemodynamic measurements and volume replacement, infusion of a wide variety of pharmacologically active agents which cannot be satisfactorily infused via peripheral veins and provision of intravenous nutrition for prolonged period of time. $^{1}$

In 1952, Aubaniac described infraclavicular subclavian technique for Central Venous Catheterisation (CVC). Later in 1962, Wilson and Associates popularised central venous catheterisation through subclavian routes. ${ }^{2}$

Ayres Gianellu, Weil and Shubin and Zimmerman considered percutaneous punctures of the saphenous, brachial, external jugular and subclavian veins in critically ill. Zimmerman points out that the saphenous vein is best avoided because of the double curve, which the catheter has to undergo to reach the right atrium. ${ }^{3}$ Bradley considers that it is inadvisable to use the femoral veins if there is any suspicion of thromboembolic disease originating from the lower extremities. ${ }^{4}$

External jugular vein became less popular, because of confluence with the subclavian vein at an inappropriate angle and the tip gets caught in the ostium of the small tributaries. ${ }^{5}$ 
Though Wilson and Associates popularised subclavian vein catheterisation, Shapira et al recommended its discontinuation due to serious complications of pneumothorax and haemothorax. ${ }^{6}$

Percutaneous right internal jugular vein cannulation can be made by landmark- or ultrasound-guided technique. The use of ultrasound and Doppler to assist internal jugular vein cannulation was reported as early as 1984.7

In literature, however, studies on using ultrasound and Doppler in IJV cannulation are minimal. Hence, we designed our study to compare between landmark and ultrasound technique for the cannulation of right internal jugular vein with regard to safety, rapidity and feasibility.

\section{METHODOLOGY}

This comparative clinical study was conducted at Kempegowda Institute of Medical Sciences and Research Centre Hospital, Bengaluru, after obtaining the Institution Ethics Committee clearance; 60 patients of either sex aged above 18 years who needed central venous pressure monitoring, long-term infusion of medications and intravenous access or with no accessible peripheral superficial veins were included in our study. Patients with severe bleeding coagulopathies, shock, trauma or infections at the neck, respiratory distress were excluded from the study.

Informed written consent was obtained from the patient or from their relative. The patients were randomly assigned for cannulation with anatomical landmarks alone or with ultrasound-guidance. The level of clinical experience of the person performing the cannulation was recorded as also the presence or absence of good anatomical landmark. Good landmarks include palpable division of the sternocleidomastoid muscle and palpable carotid artery pulse.

The age, sex, height, body mass index (Weight in Kg divided by the square of the height in metres), the circumference of the neck at the thyroid prominence and the distance from the suprasternal notch to the right mastoid process was measured. Ventilator settings were noted. Baseline vital recordings were taken and recorded on the chart. Patient was placed in supine position with 15-degree Trendelenburg position with head rotated 20-30 degrees to the left. All patients were given intradermal $1 \%$ lidocaine as local anaesthetic.

\section{Landmark Technique}

The lidocaine was injected at the site of CVC in the right SCM triangle of the neck. The finder of 21-G size was attached to 5 cc syringe containing Heparinised saline was advanced through the skin at 45-degree angle in the direction of right nipple. When venous blood was aspirated, the finder was used to guide $19-\mathrm{G}$ needle connected to $5 \mathrm{cc}$ syringe as a seeker needle. Seldinger type catheter were used with J-tip guidewire.

\section{Ultrasound-Guided Technique}

Aloka 500 Micrus 2-D ultrasound unit with $5 \mathrm{MHz}$ transducer was used. The transducer contact surface was covered with 10\% Povidone-Iodine ointment/5\% Povidone-Iodine solution, after which sterile technique was used to place the transducer into the metacarpophalangeal region of a sterile glove. Sterile $10 \%$ Povidone-Iodine solution was used as the ultrasound conductive medium between the sterile surgical glove and the patient's skin.
Ultrasound scanning was done by sonologist. Transducer was placed at 45-degree to the neck on right side with the sonologist standing next to the patient on the same side. The transducer was placed parallel and superior to the clavicular heads of the sternocleidomastoid muscle. Both internal jugular vein and carotid artery were visualised. To enlarge the size of internal jugular vein Valsalva manoeuvre was performed or if on ventilator patient is placed on inspiratory hold.

The finder needle attached to 5 cc syringe containing heparinised saline was advanced through the skin, internal jugular vein was located, the needle was visible on the screen. The finder needle was used as a guide to advance $5 \mathrm{cc}$ syringe with 19-G needle.

\section{The following Observations were made}

- The palpability of SCM and CA.

- The preparation time in seconds; time taken to prepare aseptic site for cannulation.

- The access time in seconds; the time taken for the first pass of the needle till the aspiration of the venous blood.

- Number of attempts taken to cannulate IJV.

- Whether any difficulty encountered during the procedure, difficulty to thread guidewire or catheter.

- Any complications like skin haematoma, misplacement or pneumothorax was noted.

- All the cases were subjected to CXR PA view for confirmation of catheter position.

\section{RESULTS}

There was no statistically significant difference between the two groups in respect to demographic profiles of age and sex (Graph 1 and 2), except for in BMI ( $<<0.01)$ (Table 1).

Coagulation profile between the groups were also found to be statistically insignificant (Table 2).

Haemodynamically, though there was no statistical significance between the two groups ( $p>0.068$ for systolic BP and $p>0.255$ for diastolic BP), clinically it was observed that the mean systolic blood pressure of USG technique was much higher than mean systolic blood pressure of LMG technique (Table 3).

The palpability of SCM was higher in USG technique (93.33\%) on comparison with LMG technique (66.67\%) (Graph 3).

The difference in the palpability of CA was observed to be statistically significant, where the palpability under USG technique was more (83.33\%) as compared to LMG technique (16.67\%) (Graph 4).

With respect to the neck circumference and the distance between suprasternal notch and right mastoid process in the neck, the statistical significance was not made out $(\mathrm{t}=0.562$, $\mathrm{p}>0.576)$ and $(\mathrm{t}=0.186, \mathrm{p}>0.853)$ (Table 4).

The mean \pm standard deviation for the time taken to prepare the right side of the neck by painting and draping in LMG technique was $189.83 \mathrm{sec} \pm$ SD 12.54 , whereas for the USG technique was $124.00 \mathrm{sec} \pm$ SD 36.37. There was a statistical difference with respective USG technique $(\mathrm{p}<0.0001)$. The access time in USG technique was $114.37 \mathrm{sec}$ \pm SD 87.44, whereas in LMG technique it was $268.823 \mathrm{sec} \pm$ SD 274.93 and hence the mean access time of LMG technique was much higher than that of USG technique $(\mathrm{p}<0.005)$ (Table 5).

In this study, the majority of cases in USG technique were cannulated in the first attempt $21(70.00 \%)$ followed by 
second attempt of 7 (23.34\%) cases and one case each of third and fourth attempts. However, in LMG technique only 10 (33.32\%) cases were cannulated in first attempt followed by 8 $(26.67 \%)$ cases in third attempt, followed with 5 (16.66\%) cases in fourth attempt and 5 other cases with more than 5 attempts (Graph 5).

The present study has revealed that the chest X-ray has confirmed the position of the catheter following the cannulation of right IJV in all the 30 cases of USG group and in 29 cases in LMG technique group (1 case by Carm technique) (Graph 6).
There were no serious and life-threatening complications while cannulating right IJV. In USG and LMG technique, there were only 1 and 3 cases of skin haematoma, 3 and 4 cases of carotid artery puncture. In 1 case in USG technique after 4 attempts, the cases were taken over by an experienced operator for cannulation. In LMG technique, there was bradycardia in one case while passing the catheter and ventricular ectopics while passing the guide wire in another case. There was a malposition of catheter into right axillary vein (Graph 7).

\begin{tabular}{|c|c|c|c|c|c|c|c|c|}
\hline Study Variables & Study Group & N & Mean & Std. Deviation & Std. Error Mean & T-Value & df & P-Value \\
\hline \multirow{2}{*}{ BMI } & USG Technique & 30 & 25.974 & 6.239 & 1.139 & \multirow{2}{*}{2.575} & \multirow{2}{*}{58} & \multirow{2}{*}{$<0.013$} \\
\cline { 2 - 6 } & LMG Technique & 30 & 22.214 & 5.005 & 0.9138 & & \\
\hline
\end{tabular}

\begin{tabular}{|c|c|c|c|c|c|c|c|c|}
\hline $\begin{array}{c}\text { Study } \\
\text { Variable }\end{array}$ & $\begin{array}{l}\text { Study } \\
\text { Group }\end{array}$ & $\begin{array}{c}\text { No. of } \\
\text { Subjects }\end{array}$ & $\begin{array}{l}\text { Mean } \\
(\mathrm{sec})\end{array}$ & $\begin{array}{l}\text { Std. Deviation } \\
\text { (sec) }\end{array}$ & $\begin{array}{c}\text { Std. Error } \\
\text { Mean }\end{array}$ & $\begin{array}{c}\text { T- } \\
\text { Value }\end{array}$ & df & P-Value \\
\hline \multirow{2}{*}{ BT } & $\begin{array}{c}\text { USG } \\
\text { Technique }\end{array}$ & 30 & 115.57 & 36.634 & 6.688 & \multirow{2}{*}{1.891} & \multirow{2}{*}{58} & \multirow{2}{*}{$>0.064$} \\
\hline & $\begin{array}{c}\text { LMG } \\
\text { Technique }\end{array}$ & 30 & 99.50 & 28.718 & 5.243 & & & \\
\hline \multirow{2}{*}{$\mathrm{CT}$} & $\begin{array}{c}\text { USG } \\
\text { Technique }\end{array}$ & 30 & 310.57 & 47.987 & 8.761 & \multirow{2}{*}{0.548} & \multirow{2}{*}{58} & \multirow{2}{*}{$>0.586$} \\
\hline & $\begin{array}{c}\text { LMG } \\
\text { Technique }\end{array}$ & 30 & 304.83 & 31.417 & 5.736 & & & \\
\hline \multirow{2}{*}{ Platelet Count } & $\begin{array}{c}\text { USG } \\
\text { Technique }\end{array}$ & 30 & 2.578 & 0.9140 & 0.1669 & \multirow{2}{*}{0.067} & \multirow{2}{*}{57} & \multirow{2}{*}{$>0.946$} \\
\hline & $\begin{array}{c}\text { LMG } \\
\text { Technique }\end{array}$ & 29 & 2.595 & 1.0020 & 0.1861 & & & \\
\hline
\end{tabular}

\begin{tabular}{|c|c|c|c|c|c|c|c|c|}
\hline $\begin{array}{c}\text { Study } \\
\text { Variables }\end{array}$ & $\begin{array}{l}\text { Study } \\
\text { Group }\end{array}$ & $\mathbf{N}$ & Mean & $\begin{array}{c}\text { Std. } \\
\text { Deviation }\end{array}$ & $\begin{array}{l}\text { Std. Error } \\
\text { Mean }\end{array}$ & $\begin{array}{c}\text { T- } \\
\text { Value }\end{array}$ & df & $\begin{array}{c}\text { P- } \\
\text { Value }\end{array}$ \\
\hline \multirow{2}{*}{$\begin{array}{l}\text { Systolic BP } \\
(\mathrm{mmHg})\end{array}$} & USG Technique & 30 & 121.23 & 24.939 & 4.553 & \multirow{2}{*}{1.862} & \multirow{2}{*}{56} & \multirow{2}{*}{$>0.068$} \\
\hline & LMG Technique & 28 & 109.07 & 24.774 & 4.682 & & & \\
\hline \multirow{2}{*}{$\begin{array}{c}\text { Diastolic BP } \\
\text { (mmHg) }\end{array}$} & USG Technique & 30 & 75.97 & 13.823 & 2.524 & \multirow{2}{*}{1.151} & \multirow{2}{*}{52} & \multirow{2}{*}{$>0.255$} \\
\hline & LMG Technique & 24 & 71.67 & 13.406 & 2.736 & & & \\
\hline
\end{tabular}

Table 3: Statistical Inference of Systolic BP and Diastolic BP Based on Independent Student's T-Test

\begin{tabular}{|c|c|c|c|c|c|c|c|c|}
\hline $\begin{array}{c}\text { Study } \\
\text { Variables }\end{array}$ & $\begin{array}{l}\text { Study } \\
\text { Group }\end{array}$ & $\begin{array}{c}\text { No. of } \\
\text { Subjects }\end{array}$ & $\begin{array}{l}\text { Mean } \\
(\mathrm{cm})\end{array}$ & $\begin{array}{c}\text { Std. } \\
\text { Deviation } \\
\end{array}$ & $\begin{array}{c}\text { Std. Error } \\
\text { Mean }\end{array}$ & $\begin{array}{c}\text { T- } \\
\text { Value }\end{array}$ & df & $\begin{array}{c}\text { P- } \\
\text { Value }\end{array}$ \\
\hline \multirow{2}{*}{$\begin{array}{l}\text { Neck Circumference } \\
(\mathrm{cm})\end{array}$} & $\begin{array}{c}\text { USG } \\
\text { Technique }\end{array}$ & 30 & 36.30 & 3.914 & 0.715 & \multirow{2}{*}{0.562} & \multirow{2}{*}{58} & \multirow{2}{*}{$>0.576$} \\
\hline & $\begin{array}{c}\text { LMG } \\
\text { Technique }\end{array}$ & 30 & 35.67 & 4.773 & 0.871 & & & \\
\hline \multirow{2}{*}{ Distance $(\mathrm{cm})$} & $\begin{array}{c}\text { USG } \\
\text { Technique }\end{array}$ & 30 & 16.77 & 1.813 & 0.331 & \multirow{2}{*}{0.186} & \multirow{2}{*}{58} & \multirow{2}{*}{$>0.853$} \\
\hline & $\begin{array}{c}\text { LMG } \\
\text { Technique }\end{array}$ & 30 & 16.87 & 2.315 & 0.423 & & & \\
\hline
\end{tabular}

\begin{tabular}{|c|c|c|c|c|c|c|c|c|}
\hline $\begin{array}{c}\text { Study } \\
\text { Variables }\end{array}$ & $\begin{array}{l}\text { Study } \\
\text { Group }\end{array}$ & $\begin{array}{c}\text { No. of } \\
\text { Subjects } \\
\end{array}$ & Mean & $\begin{array}{c}\text { Std. } \\
\text { Deviation }\end{array}$ & $\begin{array}{c}\text { Std. Error } \\
\text { Mean }\end{array}$ & $\begin{array}{c}\text { T- } \\
\text { Value }\end{array}$ & df & $\begin{array}{c}\text { P- } \\
\text { Value }\end{array}$ \\
\hline \multirow{2}{*}{$\begin{array}{c}\text { Preparation Time } \\
\text { (sec) }\end{array}$} & $\begin{array}{c}\text { USG } \\
\text { Technique }\end{array}$ & 30 & 189.83 & 12.540 & 2.289 & \multirow[b]{2}{*}{9.372} & \multirow{2}{*}{58} & \multirow[b]{2}{*}{$<0.0001$} \\
\hline & $\begin{array}{c}\text { LMG } \\
\text { Technique }\end{array}$ & 30 & 124.00 & 36.374 & 6.641 & & & \\
\hline \multirow{2}{*}{ Access Time (sec) } & $\begin{array}{c}\text { USG } \\
\text { Technique }\end{array}$ & 30 & 114.37 & 87.436 & 15.964 & \multirow{2}{*}{2.291} & \multirow{2}{*}{58} & \multirow{2}{*}{$>0.005$} \\
\hline & $\begin{array}{c}\text { LMG } \\
\text { Technique }\end{array}$ & 30 & 268.23 & 274.925 & 50.194 & & & \\
\hline
\end{tabular}




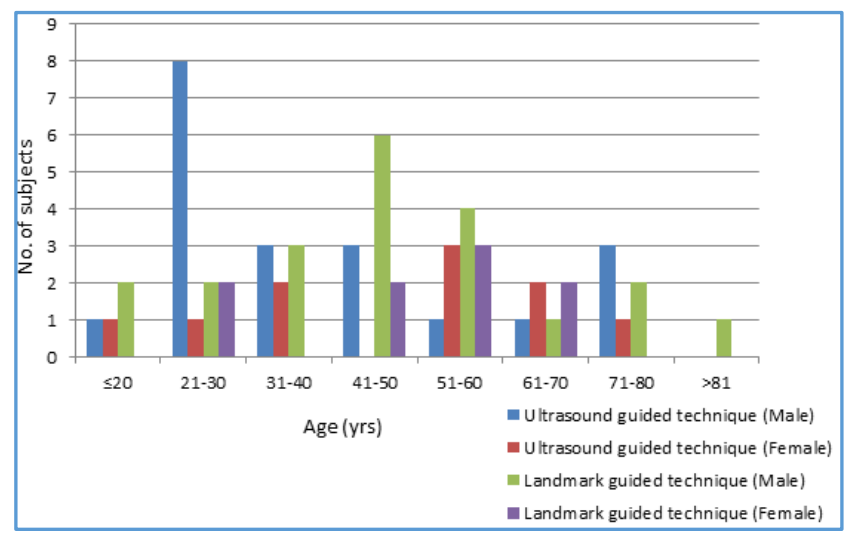

Graph 1: Bar Graph showing the Age and Sex Distribution of Subjects

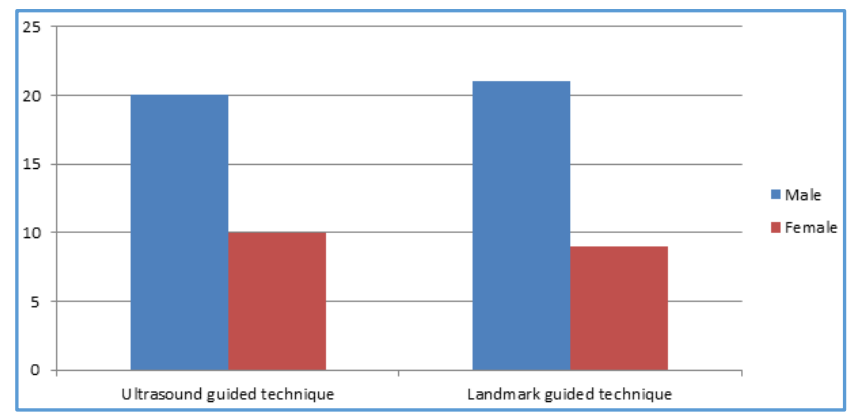

Graph 2: Bar Diagram showing the Distribution of Subjects Based on Sex

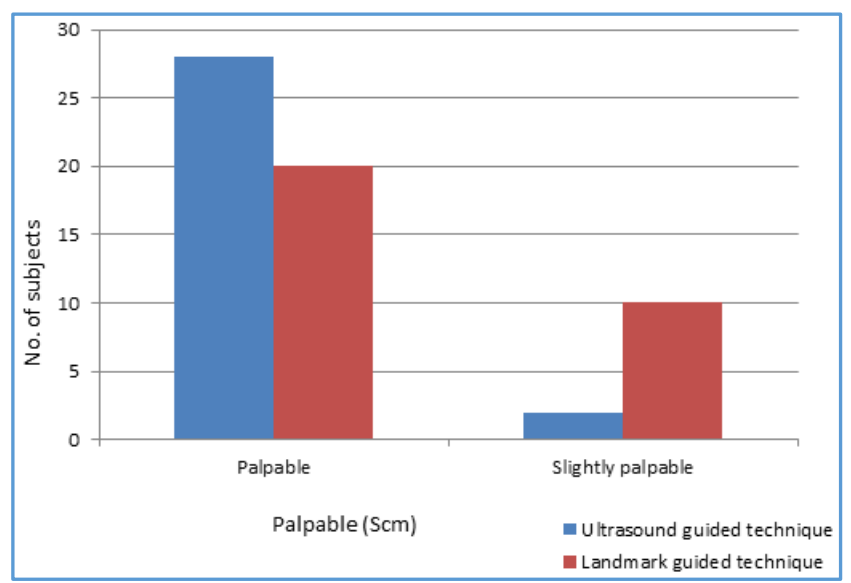

Graph 3: Bar Diagram showing the Distribution of Subjects Based on Palpable (SCM)

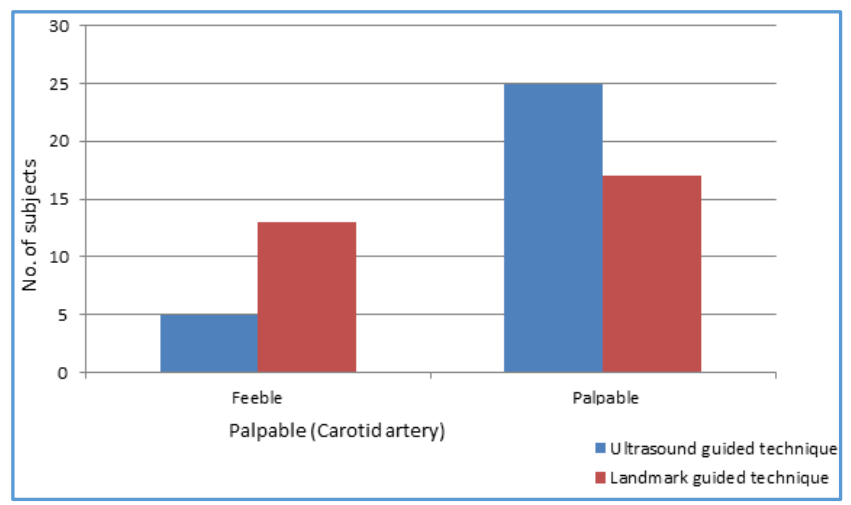

Graph 4: Bar Diagram showing the Distribution of Subjects Based on Palpable (Carotid Artery)

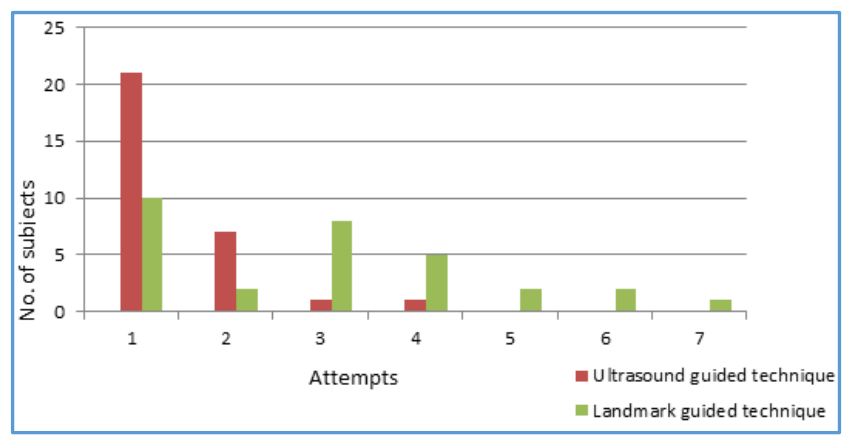

Graph 5: Bar Diagram showing the Distribution of Subjects Based on Number of Attempts

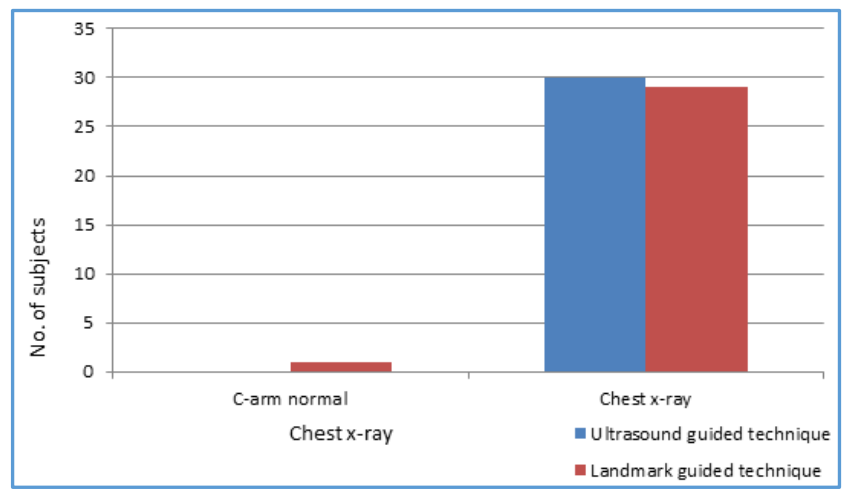

Graph 6: Bar Diagram showing the Distribution of Subjects Based on Chest X-Ray

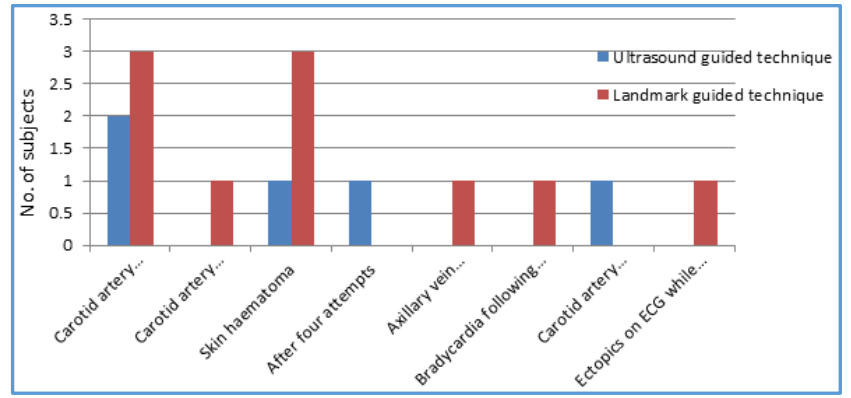

Graph 7: Bar Diagram showing the Distribution of Subjects Based on Complications

\section{DISCUSSION}

There are several techniques of CVC. There are various studies and data of different approaches and the sites of central venous cannulation. $(3,7,8,9,10,11,12,13,14,15,16)$ In this study two different techniques were employed and the approach was constant throughout, which was the central approach of CVC of right IJV.

The knowledge of the anatomy of neck is vital and the relationship of the IJV to the sternocleidomastoid muscle and $\mathrm{CA}$ is the key for understanding the position of the vein in the neck.

The position of the patient throughout the study was supine with 10-15 degrees Trendelenburg position. No patient had difficulty in lying supine. A pillow was put under the shoulder blade. The neck was rotated to left side in the range of 30-40 degrees. The triangle of sternocleidomastoid muscle comprising of sternal and clavicular heads of the SCM and the medial third of the clavicle in the neck, also the carotid artery pulsations were felt and marked. 
In landmark-guided technique, these anatomical landmarks were taken into considerations while cannulating IJV. The carotid artery was palpated in the landmark-guided technique in SCM triangle and both the finder and seeker needles were inserted lateral to CA to find the IJV.

The neck circumference and the distance from the suprasternal notch to right mastoid process was measured to know the girth and shortness or height of the neck, which has any binding on the technique. The short and thick neck cases have difficulty in appreciating the anatomical markers and so the number of attempts was more in these cases, especially in LMG technique group. There was also a difficulty of insertion with respect to obese patients for the same reason as was appreciated by the study of Defalque et $\mathrm{al}^{12}$ and Alderson et al. ${ }^{16}$ The BMI was significant statistically $(p<0.013$ ) in comparison with control. The other anthropometric measurements or age and sex had no significance in this study.

In this study throughout $5 \mathrm{MHz}, 2-\mathrm{D}$ portable ultrasound was used and was performed by a sonologist. The disadvantages of $5 \mathrm{MHz}, 2-\mathrm{D}$ portable ultrasound was the differentiation of CA and IJV by dynamic changes with each cardiac activity as with Doppler ultrasound. The limitation of 2 -D was that, though the needle was visualised in the vessel on aspiration no aspiration of blood was possible because the needle was parallel to the wall of vessel restricting the third dimension of the image. These limitations can be overcome by the 3-dimensional colour Doppler dedicated machine; however, the cost limits its use in the day-to-day practice in most of the hospitals.

The preparation time was significant $(\mathrm{p}<0.0001)$. There is no study to compare this variable with our study. The longer time taken in the USG technique group was due to the preparation of sterile probe. The infiltration of $1 \%$ lidocaine over the SCM triangle before cannulation was not taken account during the preparation time. Ideally, the wearing of cap, mask and gown was not considered in the preparation time either of the group.

The access time (Time from the preparation of the skin to the aspiration of the venous blood) included the skin passes with the finder and seeker needle together. The access time was shorter in USG technique with a mean 114.37 and standard deviation of 87.436 compared with control of mean 268.23 and standard deviation of $274.925(\mathrm{p}>0.005)$ compared with Bart G. Deny et al ${ }^{17}$ with $\mathrm{p}<0.005$.

With USG techniques, more veins were entered on the first attempt. In our study, $70.00 \%$ of USG technique vs. $33.32 \%$ of LMG technique was cannulated on the first attempt. This is in comparison with Bart G. Deny et al, $78 \%$ vs. $43.3 \%$ on first attempt and Mallory et al ${ }^{18}$ with $85 \%$ vs. $15 \%$ on first attempt of cannulation of IJV. A maximum of 7 attempts were attempted in LMG technique compared with only 4 maximum attempts in USG group. Apart from first attempt, third attempt (8-26.67\%) and fourth attempt (5-16.67\%) were maximum cannulation done by LMG group compared with second attempt ( $7-23.34 \%$ ) was the maximum cannulation attempt in USG group compared with Mallory et al with second and third attempt vs. second attempt. In only one case in USG group the case was taken over by the staff due to difficulty for cannulation of right IJV.

The complication rate were (4 - 13.33\%) in USG vs. (7 - 23.33\%) in LMG group, there was a significant decrease in complication with use of ultrasound-guided technique. There were no serious complications like pneumothorax or nerve injury on either group, but carotid artery puncture of $10 \%$ vs $13.33 \%$ comparable with Bart G. Denys ${ }^{7}$ with control, Samuel Metz et $\mathrm{al}^{19} 13 \%$ vs $27 \%$ and M. Leon skolnick ${ }^{20} 2.6$ vs $8.3 \%$ comparing USG technique vs. LMG technique. The next common complication of skin haematoma was $3.33 \%$ vs. $10 \%$ comparable with Bart G. Denys ${ }^{7} 2.66 \%$ and M. Leon Skolnick ${ }^{20}$ $3.3 \%$ in LMG technique.

The other complications related to cannulation rather than were ventricular ectopics on ECG monitor while passing the guide wire and one patient went in for bradycardia following the passage of catheter, which was treated accordingly. In one case, axillary vein was catheterised which was confirmed by chest X-ray.

The ideal placement of catheter tip is about $2-3 \mathrm{cms}$ above right atrium in the superior vena cava. There is no standard formula to measure the length of the cannula to be cannulated in SVC. But however a rough calculation of age by 10 in males and age by 12 in females is being used by some experienced operator. In this study, one case of axillary vein catheterisation was done as a complication of malposition of catheter. The catheter was repositioned as SVC and was confirmed by another chest X-ray.

In this study, the operator was constant and with no prior experience.

\section{CONCLUSION}

The study validates that the ultrasound-guided technique is superior over the traditional landmark-guided technique for the cannulation of right internal jugular vein by increase in the speed of access of the vein for cannulation, increase in the success rate of cannulation with minimal number of attempts and least discomfort of the patients. There are a few and less serious complications during CVC of right internal jugular vein even in the most inexperienced operators with USG technique. The sonological guidance of CVC is a better tool for training and teaching CVC to trainees and paramedics.

\section{REFERENCES}

1. Webb AR, Shapiro MJ, Singer M. Oxford textbook of critical care. Oxford medical publications 1990:1090-4.

2. Wilson JN, Grow JB, Demong CV, et al. Central venous pressure in optimal blood volume maintainance. Arch Surg 1962;85(4):563-78.

3. Mostert JW, Kenny GM, Murphy GP. Safe placement of central venous catheter into internal jugular veins. Arch Surg 1970;101(3):431-2.

4. Bradley RD. In: Mendel D. ed. Practice of cardiac catheterization. Oxford: Blackwell Scientific Publications 1968.

5. Craig RG, Jones RA, Sproul GS, et al. The alternative methods of central venous system catheterization. Amer J Surg 1968;34:131-4.

6. Schapira M, Stern WZ. Hazards of subclavian vein cannulation for central venous pressure monitoring. JAMA 1967;201(5):327-9.

7. Denys BG, Uretsky BF, Reddy PS. Ultrasound-assisted cannulation of the internal jugular vein. A prospective comparison to the external landmark-guided technique. Circulation 1993;87(5):1557-62. 
8. English LC, Frew RM, Pigott JF, et al. Percutaneous catheterization internal jugular vein 1969. Anaesthesia 1995;50(12):1071-6, discussion 1070.

9. Brinkman AJ, Costley DO. Internal jugular venipuntcure. JAMA 1973;223(2):182-3.

10. Jernigan WR, Gardener WC, Mahr MM, et al. Use of the internal jugular vein for placement of central venous catheter. Surg Gynecol Obstet 1970;130(3):520-4.

11. Daily PO, Grepp RB, Shumway NE. Percutenous internal jugular vein cannulation. Arch Surg 1970;101(4):534-6.

12. Defalque RJ. Percutenous catherization of the internal jugular vein. Anaesth Analg 1974;53(1):116-21.

13. Mansfield PF, Hohn DC, Fornage BD, et al. Complications and failures of subclavian-vein catheterization. New Eng J Med 1994;331(26):1735-8.

14. Machi J, Takeda J, Kakegawa T. Safe jugular and subclavian veinpuncture under ultrasonographic guidance. American Journal Surgery 1987;153(3):321-3.

15. Hatfield A, Bodenham A. Portable ultrasound for difficult central venous access. B J Anaesth 1999;82(6):822-6.
16. Alderson PJ, Burrows FA, Stemp LI, et al. Use of ultrasound to evaculate internal jugular vein anatomy and to facilitate central venous cannulation in pediatric patients. $\mathrm{Br} \mathrm{J}$ Anaesth 1993;70(2):145-8.

17. Denys BG, Uretsky BF. Anatomical variations of internal jugular vein location: impact on central venous access. Critical Care Med 1991;19(12):1516-9.

18. Mallory DL, Shawker T, Evans RG, et al. Effects of clinical maneuvers on sonographically determined internal jugular vein size during venous cannulation. Crit Care Med 1990;18(11):1269-73.

19. Metz S, Horrow JC, Balcar L. A controlled comparison of techniques for locating the internal jugular vein using ultrasonography. Anesh Analg 1984;63(7):673-9.

20. Skolnick ML. The role of sonography in the placement and mangement of jugular and subcalvian central venous catheters. American Journal Roentgenology 1994; 163(2):291-5. 